\title{
FINDING AND MINDING THE GAPS IN STATE-OF-THE-ART LEAN AND GREEN MARKETING IN THE CONSTRUCTION INDUSTRY
}

\section{PRONALAŽENJE I UTVRĐIVANJE RASKORAKA IZMEĐU SUVREMENOGA LEAN (AGILNOG) I ZELENOGA MARKETINGA U GRAĐEVINSKOJ INDUSTRIJI}

\author{
Market-Tržište \\ Vol. 32, No. 2, 2020, pp. 187-203 \\ UDK 502.12:658.8:69(01) \\ DOl http://dx.doi.org/10.22598/mt/2020.32.2.187 \\ Review
}

\begin{abstract}
Ahmet Tuz ${ }^{a}$, Begum Sertyesilisik ${ }^{b}$
a Dogus University, Construction Technology Department and Istanbul Technical University, Department of Architecture, Istanbul, TURKEY, e-mail: ahmettuz@gmail.com

b Izmir Democracy University, Department of Architecture, İzmir, TURKEY, e-mail: begum_sertyesilisik@hotmail.com
\end{abstract}

\begin{abstract}
Purpose - This paper aims to enhance sustainable development in the construction industry by presenting a literature review from the perspective of sustainable development goals (SDG) on marketing in the construction industry, its importance on management strategies, marketing capabilities, and the relationship between SDG and lean and green marketing (LGM) management in the construction industry.

Design/methodology/approach - A structured literature review was used as the research methodology to find out how the determinant topics were addressed in state-of-the-art of the literature. A total of 21 combinations of different keywords were applied to the search engine in the title, abstract, and keywords to gather research and review articles published within a period of ten years. As a result, 114 academic papers were examined.
\end{abstract}

Findings and implications - Articles were examined in three stages, focusing on: marketing and construction

\section{Sažetak}

Svrha - Cilj je rada unaprijediti održivi razvoj u građevinskoj industriji $(\mathrm{Cl})$ i predstaviti pregled literature iz perspektive ciljeva održivog razvoja (SDG) u marketingu u građevinskoj industriji (Cl), njegovoj važnosti za strategije upravljanja, marketinške sposobnosti i odnos između održivoga razvoja (SDG) i upravljanja lean (agilnim) i zelenim marketingom (LGM) u građevinskoj industriji (Cl).

Metodološki pristup - Kao metodologija istraživanja korišten je strukturirani pregled literature kako bi se saznalo na koji način su adresirane najznačajnije teme u suvremenoj literaturi. Korištena je kombinacija 21 različite ključne riječi pomoću tražilice i pretraživanja po naslovu, sažetku i ključnim riječima radi prikupljanja istraživačkih i preglednih članaka objavljenih u vremenskom razdoblju od deset godina. Ispitano je 114 znanstvenih radova.

Rezultati i implikacije - Članci su ispitivani u tri faze s naglaskom na marketingu i građevinskoj industriji $(\mathrm{Cl})$, 
industry, marketing and its importance on management, and LGM. The gaps in the literature were identified and potential future research areas were highlighted.

Limitation - Using Elsevier (www.sciencedirect.com) as the database and focusing on research and review articles written in English only are the limitations of this research.

Originality - This research contributes to the construction industry marketing literature, green marketing, and LGM in the construction industry. This research reviews the literature based on a large sample of papers in three stages. It outlines the gaps in the literature and may serve as a guide for further research of marketing and LGM strategy implementation in the construction industry.

Keywords - construction industry, green marketing, lean and green marketing, lean construction, marketing strategy, sustainable development goals marketingu i njegovoj važnosti za upravljanje te lean (agilni)i zeleni marketing (LGM). Utvrđene su jazovi u literaturi. Istaknuta su potencijalna buduća područja istraživanja.

Ograničenje - Ograničenja istraživanja vezana su uz korištenje Elseviera (www.sciencedirect.com) kao baze podataka i fokusiranje na istraživanja i pregledne članke napisane na engleskom jeziku.

Doprinos - Rad doprinosi marketinškoj literaturi u području građevinske industrije $(\mathrm{Cl})$, zelenom marketingu te lean (agilnom) marketingu u građevinskoj industriji (Cl). Istraživanje daje pregled literature na temelju velikog uzorka radova u tri faze. Prikazuje jazove u literaturi te može služiti kao vodič za daljnja istraživanja u marketingu te provedbi strategije lean (agilnog) i zelenog marketinga (LGM) u području građevinske industrije (CI).

Ključne riječi - građevinska industrija, zeleni marketing, lean (agilni) i zeleni marketing, lean (agilna) gradnja, marketinška strategija, održivi razvojni ciljevi 


\section{INTRODUCTION}

Compared with other industries, construction industry $(\mathrm{Cl})$ has unique characteristics. Attractiveness of the industry makes the construction market more competitive, with construction companies proactively seeking more advantageous strategies to differentiate in the construction market instead of sticking to the traditional management strategies. Involving unique project and project-based production (Winch, 2006), the construction industry differs from other industries in the production of end products with different characteristics (e.g., location, size, complexity) (Preece, Moodley, Smith \& Collar, 2003), by providing an output between a product and service (Maloney, 2002), and through the involvement of different parties (Li \& Wang, 2016). The North American Industry Classification System - NAICS (2017) classifies the construction industry as a product-oriented service industry under section 23 with three subindustries (p. 123). Under the International Standard Industrial Classification of All Economic Activities (ISIC) Rev. 4 (2008), the construction industry is categorized as a productive industry, subcategorized under three divisions from 41 to 43 (Department of Environmental and Social Affairs, 2008, p. 172). Moreover, the World Trade Organization (WTO) (2017) classified the construction industry as a service industry in the General Agreement on Trade in Services (GATS) in 1995.

Sustainable development (SD) has been raised as one of the major issues by governments, politicians, legislators, and several stakeholders over several decades. It challenges environmental, social and economic concerns. By incorporating environmental, social, and economic dimensions in SD pillars, the UN General Assembly formulated sustainable development goals (SDG) as being of, by, and for the humanity, which will assure the success of itself (UN, General Assembly, 2015, p. 12). Furthermore, the UN General Assembly adopted the 2030 Agenda for Sustainable Development, consisting of 17 sustainable development goals (SDG) and 169 targets, built on Millennium Development Goals (MDGs) which were set in 2020, to act in five different fields - namely, people, planet, prosperity, peace, and partnerships, called the 5Ps (Salvia, Filho, Brandli \& Griebeler, 2019).

The construction industry strives to enhance the quality of life through environmental and social SD efforts. In general, sustainable construction can be defined as the management and orientation of a built environment through efficient resource allocation and ecological management principles (Shi, Ye, Lu \& Hu, 2014). In particular, it has an activity-based focus throughout the construction project lifecycle. Therefore, it requires the adoption of creative, resourceful, and new management strategies to achieve a cleaner process and better progress (Shi et al., 2014).

Focusing on waste minimization in terms of materials, time, and efforts as well as on a maximization of performance, lean construction management (LCM) can enhance speed, quality, and sustainability performance of the construction project. Therefore, LCM enables the value created for the end customer to be maximized in terms of cost savings, high quality of the end product, and project sustainability (Marhani, Jaapar, Bari \& Zawawi, 2013). In compliance with SDG number 12 and target 12.2, which underline the importance of the efficient usage of natural resources and sustainable management, the implementation of LCM as a philosophy can contribute to a reduction in costs, as well as to a maximization of social and environmental performances, and to a minimization of waste of time, costs and material (Gomez, Raut \& Raji, 2015).

Marketing is an integrated strategic management approach to sustain and enhance companies' competitiveness in the highly competitive construction industry. It consists of an identification of consumer needs to formulate a demand-based strategy, manage the processes to satisfy consumer needs and expectations (Eneizan, Wahab, Zainon \& Obaid, 2016), and value delivery to the consumers. Marketing is one of

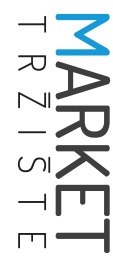




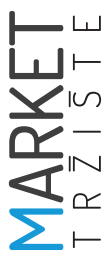

the crucial business strategy contributors which can provide orientation to construction companies moving from product-focused strategies to customer value-focused business strategies.

The pillars of sustainability can ensure companies to strategize with social and environmental concern, where managing sustainability can provide creation of environment-oriented organization values (Shi et al., 2014). Incorporating the pillars of sustainability into marketing strategies can enable companies to have sustainably Green Marketing (GM) approaches, strategies, and marketing mix tools, and in turn identify the socially and environmentally conscious companies from the consumers' perspective (Shi et al., 2014).

GM is a process management responsible for identifying, perceiving, and satisfying consumers' needs and expectations in a sustainable way (Yadav \& Pathak, 2013). Moreover, GM is compatible with SDGs that focus on the well-being of society (Prosenak, Mulej \& Snoj, 2008), and on social improvement of the short term wishes, and long-term welfare (Murin, Marková, Zeleny \& Jad'ud'ová, 2015).

GM strategies can create, deliver, and communicate value for the end customer while enhancing construction companies' corporate social responsibility, profitability, brand value, and competitiveness in the market. Moreover, GM holistically manages the green practices in all stages of production processes and supply chain (management, from the raw material procurement to product selling strategy formulation (Yadav \& Pathak, 2013). Transforming from product-focused to customer-focused strategies and considering construction projects as a whole process, GM is an integral part of the supply chain in LCM, which can be implemented in every stage of the construction process.

As part of the process, integrating GM can improve lean construction green supply chain management. The co-operation of GM and LM can be identified as a strategically sustainable management tool to provide a new marketing tool in the form of an LGM strategy. It is believed that applying LGM strategies in the construction industry can enable companies to have higher brand value, profitability, competitiveness and to improve their corporate social responsibility.

There are many academic studies on marketing, its capabilities, and management strategies (e.g., Dawson, Young, Murray \& Wilkinson, 2017; Kienzler \& Kowalkowski, 2017; Po \& Woratschek, 2017; Sanclemente-Tellez, 2017; Luo, Chen, Chen \& Wang, 2017; Hoskins, 2016); GM and its effects on management strategies (e.g., Dangelico \& Vocalelli, 2017). There is, however, limited research on the marketing in the construction industry (e.g., Badi, Wang \& Pryke, 2017; Crespin-Mazet, Havenvid \& Linne, 2015). As the combination of LCM and GM management has not yet been the focus in the literature, it is a managerial topic well worth researching.

This study aims to focus deeply on the construction management and marketing in the construction industry, combining LCM from the management perspective and GM as a marketing domain. This study also aims to enhance SD by finding the gaps in the state-of-the-art literature on LGM strategy implementation in the construction industry. The study consists of a three staged literature review; the first stage focuses on the investigation and analysis of the state-of-the-art literature on marketing in the construction industry and the relationships among marketing, the construction industry and SDGs. The impact of marketing capabilities on management is the second stage, followed by the third stage in which extant research is identified and evaluated from the perspectives of lean construction, GM management and SDGs.

\section{CONSTRUCTION INDUSTRY - LEAN MANAGEMENT - GREEN MARKETING}

The relationships among the construction industry, LCM and GM have been evaluated as part of the Industrial Organization Theory (IOT) 
with its Structure-Conduct-Performance paradigm (SCP). The IOT focuses on and conceptualizes the structure and functioning of the market where industry-related operations are carried out (Tirole, 1988), rather than focusing on individual organizational operations (Ramsey, 2001). Thereby, the IOT scrutinizes the industry and market conditions and draws attention to the influence of market structure on the companies' strategy implementation and management process (Porter, 1981), which involves strategic supply chain management. Considering SCP as a pillar of the IOT, SCP provides linkages between the companies' conduct within its supply chain management and the market structure (Ramsey, 2001). The conduct of companies operating within the boundaries of the related industry are the determinants of the industry's social, economic, and environmental performance. Figure 1 illustrates the adaptation of SCP steps to the construction industry.
With regard to its proactiveness (ISIC, 2008), the construction industry is classified as a service industry in GATS (WTO, 2017) and as a product-oriented service industry (NAICS, 2017). The unique characteristics of this industry, such as the immobility of its end product (Lovrenčić Butković \& Katavić, 2014), product-based heterogeneous production (Winch, 2006), its scope covering different product characteristic based on size, complexity, and location (Preece et al., 2003), and participation of different stakeholders (Li \& Wang, 2016), differentiate the construction industry from other service industries and make it more competitive. Hence, companies need to seek strategic management tools which will differentiate them in the construction market. Having a long supply chain process involving many suppliers, practitioners, professionals, and shareholders, the construction industry can become more sustainable and environmentally friendly industry through the implementation of new management and marketing strategies complying with SDGs (Figure 2).

FIGURE 1: Adaptation of SCP steps to construction industry

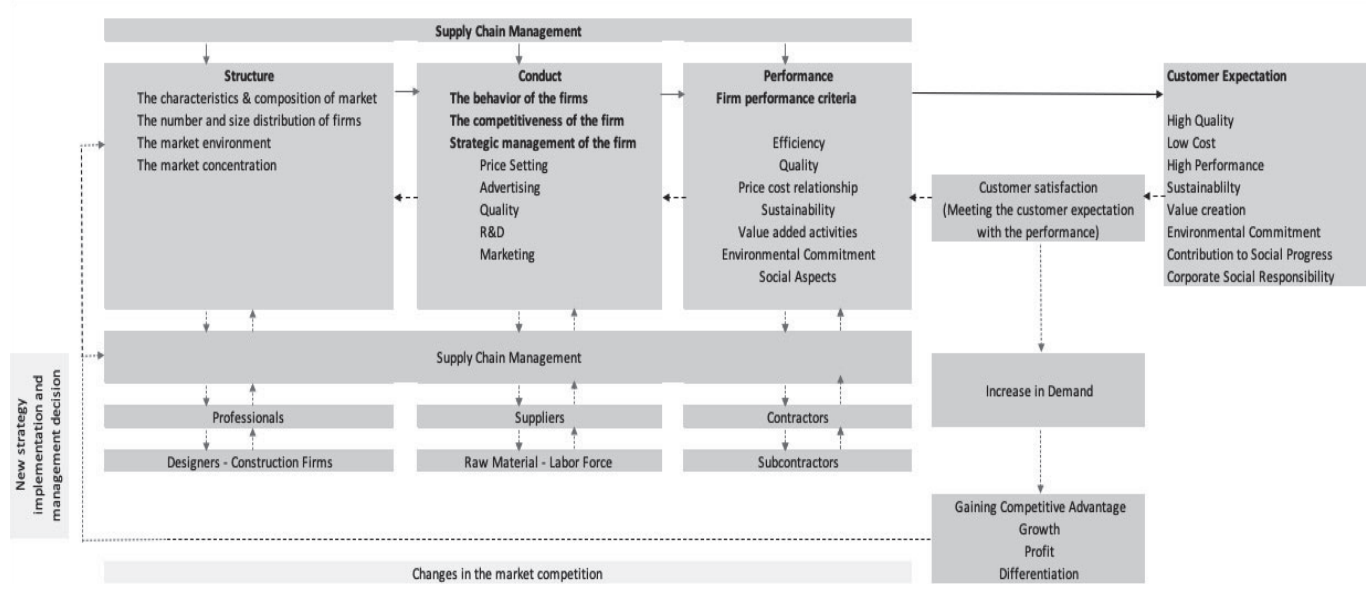




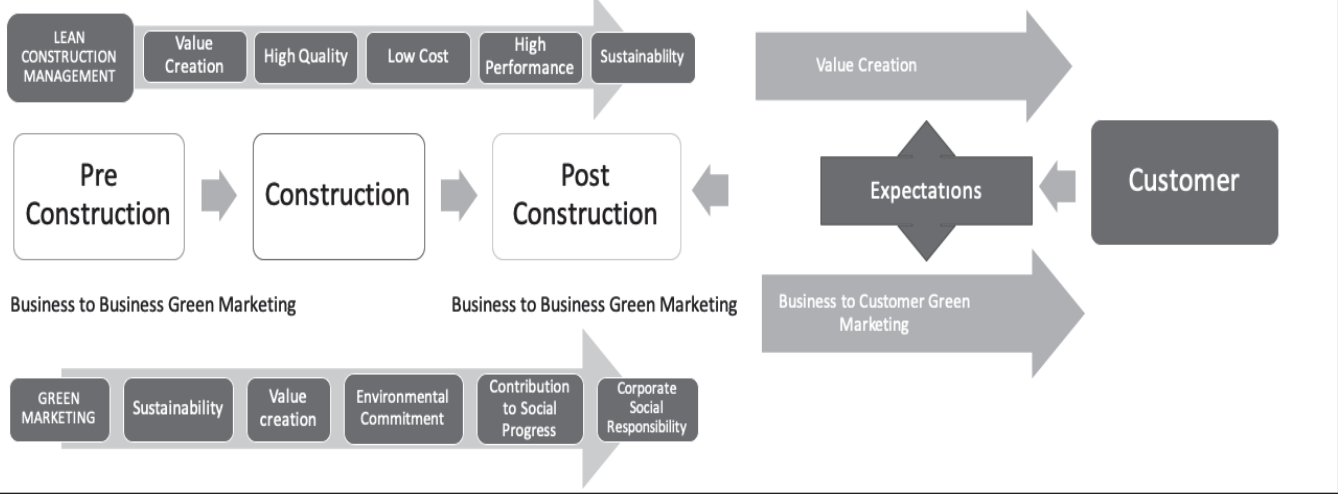

Considering sustainability and sustainable development as criteria in the processes involved in construction projects, LCM combines the construction companies' organizational performance with sustainability. Thus, LCM creates value for customers by reducing its environmental footprint. GM plays significant roles in all stages of construction supply chain management process, in which stakeholders have business-to-business (B2B) GM relations while applying business-to-customer (B2C) GM strategies when facing end-customers. Both meet the expectations of green consumers through sustainable value creation.

Green consumer involvement in all stages of construction supply chain plays a significant role in transition to a green circular economy (Chamberlin \& Boks, 2018). Increase in customers' green involvement in both construction and post-construction stages give rise to new supply chain tasks for construction companies from the LCM, GM, and sustainable consumption perspectives (Chamberlin \& Boks, 2018). The concurrency of LCM and GM implementation can support sustainable value creation for customers and reduce the construction industry's carbon footprint. In line with the definition of UN SDG number 12, "Providing sustainable consumption and production patterns" (UN, 2016), this cooperation can help the production of long-term marketing-oriented products fo- cused on environmental prosperity for the present and the future.

\section{RESEARCH METHODS}

Literature review is an important progression step in the creation of structure of the research area as well as in the identification and content conceptualization of the research field (Cherrafi, Elfezazi, Chiarini, Mokhlis \& Benhida, 2016). Structured literature review is used to identify and evaluate the publications systematically and explicitly (Fink, 2013, as cited in Zhu \& Sarkis, 2016). It involves enhanced descriptive analysis by adding subsequent review analysis, which is adopted from Kienzler and Kowalkowski (2017). Table 1 represents the research method overview whereas Table 2 shows the four successive stages of research method implementation.

Table 1: Research method overview

\begin{tabular}{|c|c|}
\hline Type of analysis & Qualitative \\
\hline Search engine & $\begin{array}{l}\text { Elsevier (www. } \\
\text { sciencedirect.com) }\end{array}$ \\
\hline Search in & Keywords, Title, Abstracts \\
\hline $\begin{array}{l}\text { Data range } \\
\text { (Time period) }\end{array}$ & $2008-2017$ \\
\hline Language & English \\
\hline \multirow{2}{*}{ Document type } & \begin{tabular}{l|l|} 
1. & Research articles \\
\end{tabular} \\
\hline & 2. Review articles \\
\hline
\end{tabular}


TABLE 2: Diagram of the structured literature review process

\begin{tabular}{|c|c|c|c|}
\hline $\begin{array}{c}\text { 1. Focus } \\
\text { determination }\end{array}$ & 1.1. Determination of the aim & & $\begin{array}{c}\text { 1.2. Keyword } \\
\text { selection }\end{array}$ \\
\hline $\begin{array}{c}\text { 2. Content } \\
\text { analysis }\end{array}$ & $\begin{array}{c}\text { 2.1. Selection of an } \\
\text { appropriate sampling frame }\end{array}$ & 2.2. Keyword driven search & $\begin{array}{c}\text { 2.3. Publication } \\
\text { collection }\end{array}$ \\
\hline $\begin{array}{c}\text { 3. Descriptive } \\
\text { analysis }\end{array}$ & 3.1. Classification of relevance & 3.2. Subsequent review & $\begin{array}{c}\text { 3.3. Data } \\
\text { extraction }\end{array}$ \\
\hline & \multicolumn{3}{|c|}{ 4. Data analysis \& synthesis } \\
\hline
\end{tabular}

In the first stage, the target is to analyze the literature to find out how the determinant subjects of the study are addressed in the state-of-theart literature. The keyword combinations are set and Elsevier (www.sciencedirect.com) is used as a search engine to identify the appropriate sampling of the academic publications. Content analysis is applied in the second stage, which corresponds to the progress investigation over a long period of time and provides a systematic quantitative evaluation of the appropriate sampling of the academic publications (Kienzler \& Kowalkowski, 2017). Keyword combination driven search is applied to the database for papers published within a period of ten years. There are 21 keyword combinations used to review the literature (Figure 3). Deductive method has been used to determine the historical development progression. The database is searched by title, abstract, and keywords by using a set of keyword combinations using the boolean operator (AND). Descriptive analysis is applied in the third stage of the research methodology, which comprises the relevance classification, the subsequent review analysis, and the data extraction from the sampling frame obtained from the database. Classification by relevance confirms whether the publications match the main aim of the study, while a subsequent review analysis determines the primary, secondary, and market focuses of the publications. The elimination of irrelevant academic studies continues with data extraction, which involves a classification of the publications with respect to the journal name, its publication year, geographical distribution, the primary focus of such studies, their secondary focus, market focus, and the research design implemented.

Gap analysis is the methodology which highlights any unaddressed topics in the current literature which need covering and improve their integration with future investigations and research (Mineraud, Mazhelis, Su \& Tarkoma, 2016), determination of the steps to consider in making progress from the current to the desired position, thus paving the way for the academia and researchers to proceed to new research topics. Analyzing and synthesizing the stressed and argued points of the examined academic papers, gap analysis is implemented from the construction industry, marketing domain, and LGM strategies perspectives.

\section{LITERATURE REVIEW ANALYSIS}

The structured literature review is conducted at three different stages, which consist of different research areas: (1) marketing and construction industry, (2) marketing capabilities, their importance on management strategies, and (3) GM capabilities, lean and marketing, lean and GM, lean GM, and SDG relations. The literature review analysis is summarized in Figure 3. 
FIGURE 3: Stages and results of literature review analysis

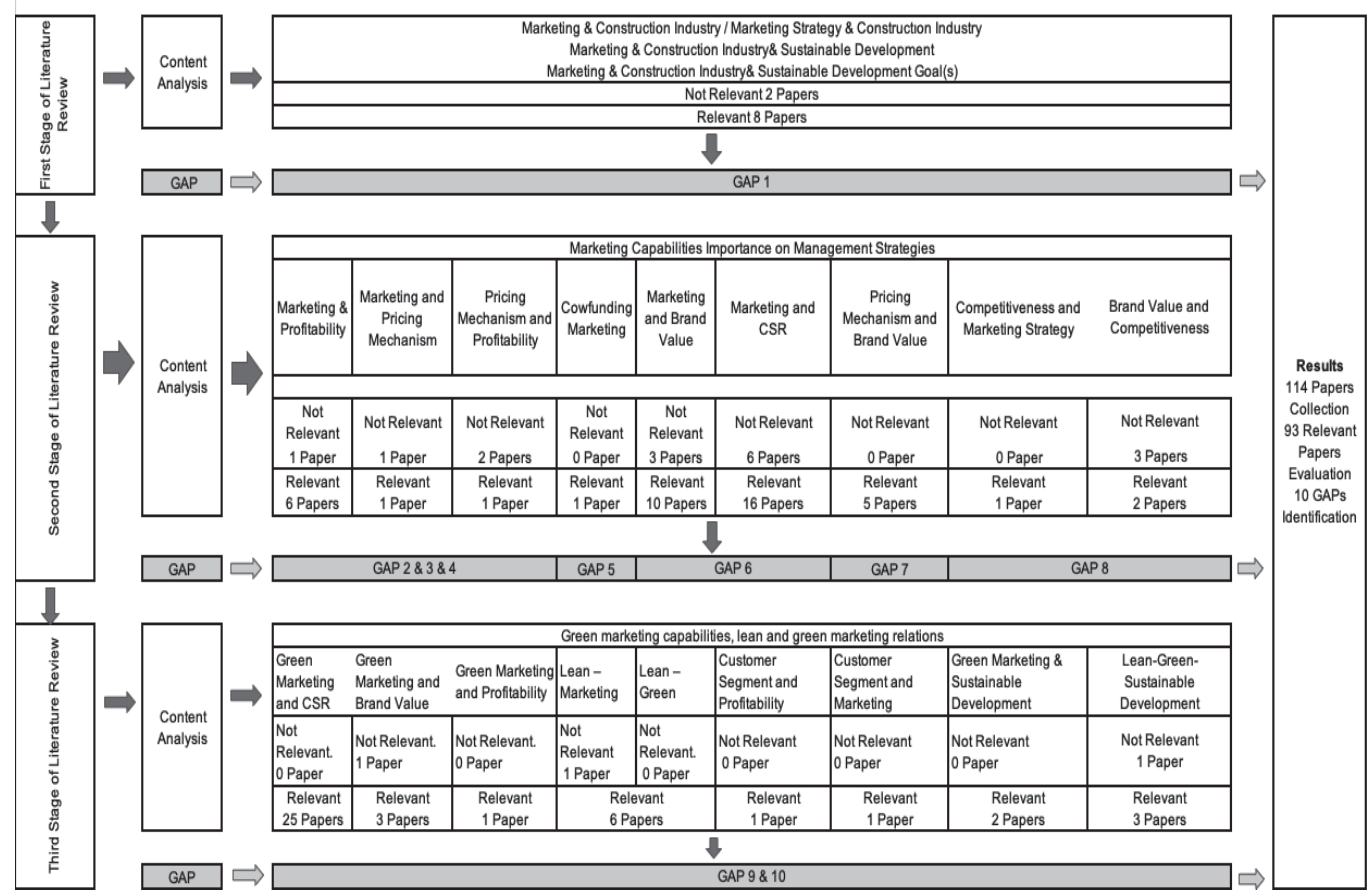

\subsection{First stage of the structured literature review}

In the first stage of the literature review, the aim is to find the marketing management focus in the construction industry and how marketing activities are related to the construction industry and SDGs. Eight papers are evaluated to understand how marketing in the construction industry has been addressed. The majority of publications have focused on general marketing activities. Zhou and Chiang (2013) analyze marketing promotional activity barriers, while Setiawan, Erdogan and Ogunlana (2015) investigate the effect of proactiveness and proactive marketing strategies' on expanding marketing activities and market segments in the competitive environment. Badi and others (2017) analyze the relationship marketing between the construction company and the stakeholders. Crespin-Mazet and others (2015) evaluate how construction partnering and project stakeholder relationships affect project marketing and in- fluence customer selections. Qi and Chen (2014) determine the marketing and competition paradigm effect on the project management in the construction industry in terms of efficiency and productivity. Jensen (2017) examines the lack of staged competition, benchmarking, and innovative solutions in the construction industry, while Haddadi, Hosseini, Johansen and Olsson (2017) investigate how value can be created and managed in the construction industry from a marketing perspective.

Even if the construction industry is characterized as a highly competitive industry, there are limited academic and research studies on marketing in this particular industry. As a sum of proactive strategies, marketing provides competitive advantages and sustains the competitiveness and position of companies in the market by value creation for customers. Within the time period under observation, however, a limited number of published academic articles on marketing in the construction industry focuses on different 
topics (e.g., relationship marketing, project marketing, proactiveness, networking, and value management). Moreover, there is an absence of focus on the SDG perspective in the construction industry marketing management. The first gap in the literature has been identified based on the results of the first stage of the structured literature review.

GAP 1: There is a lack of SDG marketing focus in the construction industry.

\subsection{Second stage of the structured literature review}

The structured literature review methodology was redefined to find out why marketing is crucial from the management perspective. Therefore, as shown in Figure 3, nine different keyword combinations were determined. With regard to the aim of this literature review, 59 publications were found in total, of which 43 directly related papers were evaluated to understand the effects of marketing on management strategies.

According to in-depth analysis of academic publications obtained from the database, all marketing strategies/analyses have been evaluated. The 43 articles identified were classified according to the sectors they examined. Most of these papers focus on fast moving consumer goods (product-based industry) which have a short product lifecycle. These are beverages (Dawes, Bond, Hartnett \& Sharp, 2017; Po \& Woratschek, 2017), daily consuming products (Luo et al., 2017; Beneke \& Carter, 2015), personal care and cosmetic products (Dawes et al., 2017, Salamandic, Alijosiene \& Gudonaviciene,2014), and electronic devices (Wang \& Tzeng, 2012; Grimmer \& Bingham, 2013). Figure 4 illustrates the distribution of papers based on their market focus. All 43 papers were classified according to their market focus: 19 papers were found to have a fast-moving consumer good based (product-based) focus, while the remaining 24 papers have a strategy-based market focus. All the B2C related publications were product based, whereas only one paper related to the
B2B market focus was related to product-based marketing activities.

\section{FIGURE 4: Distribution of academic publications based on their market focus}

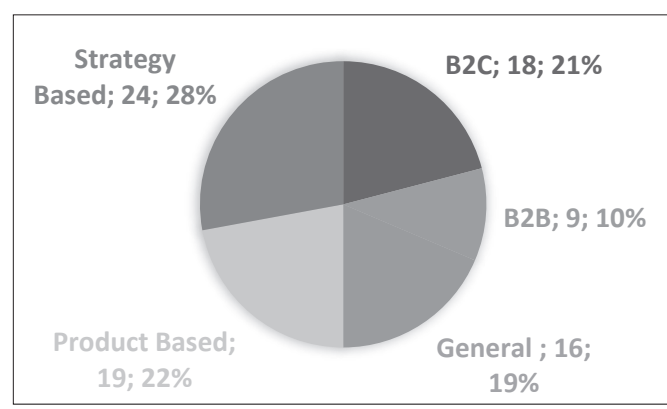

GAP 2: There is a lack of SDG-oriented marketing strategies/analyses related to the service sector in the literature.

\subsubsection{Marketing, profitability, and pricing mechanism}

Kienzler and Kowalkowski (2017) indicate that the pricing strategy, from the traditional marketing perspective, targets profit maximization and revenue creation. Marjanova, Sofijanova, Davce and Temjanovski (2015) claim that marketing provides companies with competition-oriented strategies as part of their market-oriented strategies, which have significant effects on financial performance. Moreover, Marjanova and others (2015) remark that competition-oriented company strategies enable a definition of customer expectations; marketing-oriented strategies can contribute to the satisfaction of customer needs, which can in turn increase the perceived customer value and provide profit maximization.

According to D'Haen, Poel and Thorleuchter (2013), many companies classify customers based on their current and projected future profitability and pay attention to the more profitable existing customers. Rust, Kumar and Venkatesan (2011), however, underline the fact that differentiation in the market allows companies to attract new customers and enhance customer satisfaction.

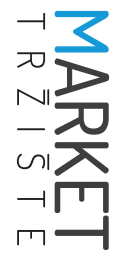


Dawson and others (2017) indicate that in B2B customer involvement, communication, innovation, and customer expectation focused relationship marketing can increase profit. Moreover, Dhanora, Sharma and Khachoo (2018) consider differentiation in the product from the technological perspective as improvement of the product and process in the supply chain that can provide cost reduction as well as attract new customers. Moreover, innovation in marketing strategies (e.g., product design, promotional and pricing methods, packaging) and organizational innovations (e.g., new managerial practices, which can help improve productivity of labor and reduce transaction costs) can directly affect the market power and profitability. Additionally, Hinterhuber (2016) emphasizes that differentiation and innovation creating value for customers can enable companies to identify customer segments which will be less sensitive to price, repeat purchasing behavior and have higher brand loyalty and value.

GAP 3: There is a lack of GM options which can enhance the SDGs to create less price sensitive niche segments.

GAP 4: There is a lack of studies focusing on LM tool application-oriented product and process innovation.

\subsubsection{Price mechanism and brand value}

Boyle and Lathrop (2013) define the price without considering customer value as a reliable predictor of quality, as higher prices point to higher-quality brands. Beneke and Carter (2015), however, state that customer value depends on the perceived quality and price, which directly affects customers' purchase intention. Additionally, Dawes and others (2017) emphasize that the unique/differentiated products increase the perceived value and provide niche branding, making customers less price sensitive. Salamandic and others (2014) indicate that brand awareness can reduce price sensitivity of customers and increase brand loyalty, enabling low demand elasticity and high profits. Luo and others
(2017) underline that the pricing strategy in the SC management, from the customer perspective, depends on the perceived customer value and brand preferences while being related to quality and brand awareness from the product perspective.

GAP 5: There is a lack of focus in the literature on the relationship between product environmental criteria and the LM philosophy, and the production of high-quality low-cost products.

\subsubsection{Marketing and brand value}

Wang and Tzeng (2012) focus on brand-related marketing strategy and define brand as a simple product purchase decision tool, which can satisfy the consumer needs by differentiation. So, King, Hudson and Meng (2017) claim that the identification of brand is not the determinant of brand awareness, as customer brand perception makes the brand attractive. Moreover, Po and Woratschek (2017) focus on relationship marketing and brand value. Himme and Fischer (2014) define customer satisfaction and brand value as non-financial metrics which have vital effect on profitability. Brand value focuses on product, while customer satisfaction focuses on customer (Himme \& Fischer, 2014). Zhang, Jiang, Shabbir, and Du (2015) define marketing capability and networking as outside in capabilities building up brand equity, and innovation capability as inside-out capability impacting brand equity and improving customer value. Himme and Fischer (2014) highlight that higher investment in marketing provides companies with stronger brand equity among customers. Sacui and Dumitru (2014) focus on creating differentiation by market-based asset management to ensure and create shareholder value. Marketing expenditure, which is classified as capital investment, provides brand awareness and brand value affecting companies' performance in the short and long term.

GAP 6: There is a lack of marketing focus on the social benefits of the brand (e.g., environmental factors). 


\subsubsection{Brand value and competitiveness}

In their 2013 research study, Santoz-Vijande, Rio-Lanza, Suarez-Alvarez and Diaz-Martin focused on a brand management system which can enable companies to have a dynamic capability to adapt to the rapid market pace. Santoz-Vijande and others (2013) posit that being a strong brand is crucial for the long-term competitiveness and also emphasize that innovation and market orientation, which can be defined as valuable components of the strong brand, have positive effects on the company's financial performance. Hoskins (2016) discusses branding from the supply chain management perspective and stresses that offering value to customers by reducing marketing costs can cause low cost-low quality perceptions. Olbrich, Jansen and Hundt (2017) state that the quality and price perception affect the customers' purchasing behavior. Melovic, Ishkov and Romanovich (2016) underline that brand represents a significant source of corporate competitiveness, which means retaining existing customer to customer relationships, while attracting new customers by creating awareness.

GAP 7: There is a lack of academic papers related to the social and environmental product features and GM.

\subsubsection{Marketing and corporate social responsibility}

Grimmer and Bingham (2013) state that combining branding strategy with environmentalism can ensure that companies have environmental brand image. Researchers additionally indicate that customers' purchase intention can be affected by perceived environmental performance of each company, and that customers who are more involved in the environment have lower price sensitiveness and can be more willing to buy high-priced environmentally friendly products for reasons of ethical trade. Moreover, Gadeikiene and Banyte (2015) emphasize that consumer buying behavior can be influenced by corporate social responsibility (CSR) activities of the company. Sanclemente-Tellez (2017) analyzes how CSR has been addressed in marketing and establishes the following classification: cause-related marketing, social marketing, and environmental marketing. Shang, Basil and Wymer (2010) define social marketing as a voluntary behavior change for individuals and the society through donations, considering environmental issues which can increase the customer purchase intention. Lacey, Close, and Finney (2010) and Scheinbaum and Lacey (2015) focus on event marketing in sports, which points out social responsibility of companies. The authors emphasize that sharing marketing budget for event sponsorship can give companies greater customer loyalty. Hartmann, Klink, and Simons (2015) investigate how cause-related marketing can motivate customers to donate through their purchase decision. These authors focus on food industry while other researchers (e.g., Lucke \& Heinze, 2015; Vveinhardt \& Zygmantaite, 2015) examine daily consumption products. The 2017 research by Ma, Shang, and Wang on CSR in the supply chain management of high-tech products and food markets reveals that suppliers invest in CSR as well as increase demand and customer value, while the retailer can attempt to influence demand through its marketing capabilities.

GAP 8: There is a lack of publications related to the environmental marketing and service industry.

\subsection{Third stage of the structured literature review}

The third stage of the structured literature review aims to identify the current relationship between the GM focus and LCM in the construction industry before evaluating and analyzing the published articles to identify any gaps in the literature. A total of 42 out of 45 academic papers were evaluated to understand the relationship between LM and GM focus and the way this relationship has been addressed.

\subsubsection{GM and CSR - lean \&green}

Chan, He, and Wang (2012) focus on green industrial products and strategies which are

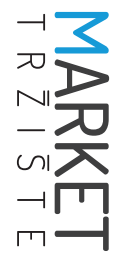




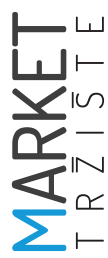

based on green B2B marketing and green organizational purchase behavior. Researchers investigate a green industrial brand which requires the integration of GM and GSC management. Chan (2013) looked into the GM strategy to identify four main green strategies, as follows: the lean-green strategy, the defensive strategy, the shaded strategy, and the extreme strategy. According to Chan (2013), the lean-green strategy is not an adoptable and promotable strategy, which tries only to reduce costs and does not focus on green initiatives. Brindley and Oxborrow (2014), however, highlight that GM and GSC management cannot be considered separately. Rather, they defined GM as synthesizing environmental issues with marketing process strategically, while managing demand, developing product/service, and improving supply chain management with pull factor implementation. Quoquab and Mohammad (2016) investigate the marketing paradigm shifts from the traditional to environment-dominant logic. Researchers stressed that environmentally oriented marketing strategies that focus on environmental well-being can improve zero waste and zero pollution orientation during all production stages (Quoquab \& Mohammad, 2016).

Garza-Reyes' 2015 research on the relationship between lean and green, reveals six research areas, where lean and green are concurrent and can effectively work together. These areas can be listed as: their compatibility, integration, amalgamation, integration with other paradigms, contributions on organizational performance, and their implication on the industries (Garza-Reyes, 2015). Verrier, Rose and Caillaud (2016) created a greenhouse model, which points out green and lean co-operations as a strategically sustainable management tool.

GAP 9: There are limited publications focusing on LGM and there is a lack of publications dealing with $L M$ 's direct relationship with GM.

\subsubsection{GM and SD}

Kushawa and Sharma (2016) focus on how green initiatives (e.g., GM, GSC management, green product innovation, eco-labeling) can affect corporate targets and on the relationship of these initiatives with SD; they concluded that green initiatives that can positively and directly affect the targets of companies and enhance their contribution to SD. Simão and Lisboa (2017) analyze how GM and sustainability can be contextualized in companies' management strategies to become a green brand.

\subsubsection{Lean, green and SD}

Regarding the SDGs, Hajmohammad, Vachon, Klassen and Gavronski (2013) focus on the way in which lean SC management can contribute to the improvement of environmental performance of companies. Wu, Low and Jin (2013) examine how LM implementation reduces carbon emission levels in the precast concrete installation. Verrier and others (2016) directed their focus on the lean and green link with value creation purpose, creating a framework for the companies to benchmark to enhance their performance.

GAP 10: There are limited publications focusing on LGM and SD (goals).

\section{POTENTIAL FUTURE RESEARCH DIRECTIONS}

Marketing activities are part of strategic management. Due to the limitations of this research, focusing on research studies and articles from different databases can provide potential future research topics for researchers. Future research areas may be found based on an in-depth structured literature review and gap analysis, focusing on the gaps identified in this research.

Since there is a lack of SDG-oriented marketing activities in the construction industry, the development of marketing with a focus on SDGs in that particulary industry, as well as the exploration of service industry-based marketing strategies/analysis based on SDGs can provide potential future research topics.

There is a lack of GM options in the literature about the development of SDGs to create a less 
price sensitive niche segment. Examining the effects of GM on profitability and price mechanism can create a research topic for future studies. Furthermore, focusing on the application of LM tools on product and process innovation from the perspective of marketing, profitability and price mechanism can create another opportunity for future research.

Focusing on SDGs, specifically Number 12 and Number 11, from the lean and green relationship perspective as well as analyzing the implementation of Number 3 and Number 9 in the construction industry context can create potential future research areas too.

Determining and researching the social benefits and environmental factors of marketing on brand value, researching the relationship between GM and brand value, researching CSR in the service industry, and researching the implementation of LGM strategies are also among topics for researchers. Finally, there may be an opportunity for researchers to focus deeply on the relationship between lean-green and SDGs in the construction industry. Introducing LGM strategy to the literature can provide construction companies with the advantage of transforming their construction processes to have zero waste and pollution in production, while enabling them to produce products with green and sustainable marketing features.

\section{CONCLUSION}

In this study, a three-stage structured literature review focused on marketing and the construc- tion industry, marketing capabilities, effects, importance, as well as on management strategies, GM capabilities, lean and GM relations. It was aimed at identifying the gaps in the literature to enhance LGM, which is an emerging issue in the field. According to the systematic literature review results, 114 papers have been published within a period of ten years; 93 papers were found to be relevant for the scope of this research. Descriptive analysis was performed and data extracted from all papers. A total of 10 gaps have been identified for further research. Using Elsevier (www.sciencedirect.com) as the database, focusing on research and review articles written in English only are the limitations of this research.

This paper contributes to the literature on SDGs in the construction industry marketing, GM in the construction industry and LGM in the construction industry. Gaps and topics found in the literature (e.g., lack of SDG focus of the construction marketing, LGM strategy application, and GM in the construction industry) were addressed. Thus, this study is expected to serve as a guide for further research studies to enhance the exploration of marketing as well as LGM strategy implementation in the construction industry.

\section{ACKNOWLEDGEMENT:}

This paper has been prepared within the scope of and based on the PhD dissertation studies and researches of the Ph.D. candidate Mr. Ahmet Tuz and his Ph.D. supervisor Prof. Dr. Begum Sertyesilisik.

\section{References}

1. Badi, S., Wang, L., \& Pryke, S. (2017). Relationship Marketing in Guanxi Networks: A Social Network Analysis Study of Chinese Construction Small and Medium-sized Enterprises. Industrial Marketing Management, 60, 204-218.

2. Beneke, J., \& Carter, S. (2015). The development of a consumer value proposition of private label brands and the application thereof in a South African retail context. Journal of Retailing and Consumer Services, 25, 22-35.

3. Boyle, P. J., \& Lathrop, E. S. (2013). The value of private label brands to U.S. consumers: an objective and subjective assessment. Journal of Retailing and Consumer Services, 20, 80-86. 
4. Brindley, C., \& Oxborrow, L. (2014). Aligning the sustainable supply chain to GM needs: A case study. Industrial Marketing Management, 43, 45-55.

5. Chamberlin, L., \& Boks, C. (2018). Marketing approaches for a circular economy: using design frameworks to interpret online communications. Sustainability, 10, 20-29.

6. Chan, E. S. W. (2013). Managing GM: Hong Kong hotel managers' perspective. International Journal of Hospitality Management, 34, 442-461.

7. Chan, H. K., He, H., \& Wang, W. Y. C. (2012). GM and its impact on supply chain management in industrial markets. Industrial Marketing Management, 41, 557-562.

8. Cherrafi, A., Elfezazi, S., Chiarini, A., Mokhlis, A., \& Benhida, K. (2016). The integration of lean manufacturing, six sigma and sustainability: A literature review and future research directions for developing a specific model. Journal of Cleaner Production, 139, 828-846.

9. Crespin-Mazet, F., Havenvid, M. I., \& Linne, A. (2015). Antecedents of project partnering in the construction industry - The impact of relationship history. Industrial Marketing Management, 50, 4-15.

10. D'Haen, J., Poel, D. V., \& Thorleuchter, D. (2013). Predicting customer profitability during acquisition: finding the optimal combination of data source and data mining technique. Expert Systems with Applications, 40, 2007-2012.

11. Dangelico, R. M., \& Vocalelli, D. (2017). "GM": An analysis of definitions, strategy steps, and tools through a systematic review of the literature. Journal of Cleaner Production, 165, 1263-1279.

12. Dawes, J., Bond, A., Hartnett, N., \& Sharp, B. (2017). Does double jeopardy apply using average spend per buyer as the loyalty metric?. Australasian Marketing Journal, 50, 4-15.

13. Dawson, B., Young, L., Murray, J. M., \& Wilkinson, I. (2017). Drivers of supplier-customer relationship profitability in China: Assessing international joint ventures versus state owned enterprises. Industrial Marketing Management, 66, 29-41.

14. Dhanora, M., Sharma, R., \& Khachoo, Q. (2018). Non-linear impact of product and process innovations on market power: A theoretical and empirical investigation. Economic Modelling, 70, 67-77.

15. Eneizan, B. M., Wahab, K. A., Zainon, M. S., \& Obaid T. F. (2016). Prior research on GM and GM strategy: critical analysis. Singaporean Journal of Business Economics and Management Studies, 5(5), 1-19.

16. Executive Office of the President Office of Management and Budget (2017). North American Industry Classification System (NAICS). United States.

17. Gadeikiene, A., \& Banyte, J. (2015). Discourse on corporate social responsibility in the context of marketing scientific research. Procedia Social and Behavioral Sciences, 213, 702-708.

18. Garza-Reyes, J. A. (2015). Lean and green - a systematic review of the state-of-the-art literature. Journal of Cleaner Production, 102, 18-29.

19. Gomez, C. P., Raut, A., \& Raji, A. U. (2015). Generating value at preconstruction: minding the gap in lean architectural practice. Proceedings IGLC-15, Perth, Australia.

20. Grimmer, M., \& Bingham, T. (2013). Company environmental performance and consumer purchase intentions. Journal of Business Research, 66, 1945-1953.

21. Haddadi, A., Hosseini, A., Johansen, A., \& Olsson, N. (2017). Pursuing value creation in construction by research - A study of applied research methodologies. Procedia Computer Science, 21, 1080-1087.

22. Hajmohammad, S., Vachon, S., Klassen R. D., \& Gavronski, I. (2013). LM and supply management: their role in green practices and performance. Journal of Cleaner Production, 39, 312-320.

23. Hartmann, M., Klink, J., \& Simons, J. (2015). Cause related marketing in the German retail sector: Exploring the role of consumers' trust. Food Policy, 52, 108-114.

24. Himme, A., \& Fischer, M. (2014). Drivers of the cost of capital: The joint role of non-financial metrics. International Journal of Research in Marketing, 31, 224-238. 
25. Hinterhuber, A. (2016). The six pricing myths that kill profits. Business Horizons, 59, 71-83.

26. Hoskins, J. D. (2016). Offering value and capturing surplus: A strategy for private label sales in a new customer loyalty building scenario. Journal of Retailing and Consumer Services, 28, 274-280.

27. Jensen, C. A. (2017). Staged competition as a driver of construction innovation. Procedia Engineering, 196, 872-879.

28. Kienzler, M., \& Kowalkowski, C. (2017). Pricing strategy: A review of 22 years of marketing research. Journal of Business Research, 78, 101-110.

29. Kushawa, G. S., \& Sharma, N. K. (2016). Green initiatives: A step towards sustainable development and firm's performance in the automobile industry. Journal of Cleaner Production, 121, 116-129.

30. Lacey, R., Close, A. G., \& Finney, R. Z. (2010). The pivotal roles of product knowledge and corporate social responsibility in event sponsorship effectiveness. Journal of Business Research, 63, 1222-1228.

31. Li, W., \& Wang, X. (2016). Innovations on management of sustainable construction in a large earthwork project: An Australian case research. Procedia Engineering, 145, 677-684.

32. Lovrenčić Butković, L., \& Katavić, M. (2014). Marketing perspectives for the construction sector. $6^{\text {th }}$ International Scientific Conference on Economic and Social Development and $3^{\text {rd }}$ Eastern European ESD Conference: Business Continuity, 24-25 April 2014, Vienna, 175-184.

33. Lucke, S., \& Heinze, J. (2015). The role of choice in cause-related marketing - investigating the underlying mechanisms of cause and product involvement. Procedia Social and Behavioral Sciences, 213, 647-653.

34. Luo, Z., Chen, X., Chen, J., \& Wang, X. (2017). Optimal pricing policies for differentiated brands under different supply chain power structures. European Journal of Operational Research, 259, 437-451.

35. Ma, P., Shang, J., \& Wang, H. (2017). Enhancing corporate social responsibility: Contract design under information asymmetry. Omega, 67, 19-30.

36. Maloney, W. (2002). Construction product/service and customer satisfaction. Journal of Construction Engineering and Management, 128(6), 522-529.

37. Marhani, M. A., Jaapar, A., Bari, N. A. A., \& Zawawi, M. (2013). Sustainability through lean construction approach: a literature review. Social and Behavioral Sciences, 101, 90-99.

38. Marjanova, T. J., Sofijanova, E., Davce, L., \& Temjanovski, R. (2015). Entrepreneurial competition orientation and profitability: The case of a developing economy. Procedia Social and Behavioral Sciences, 207, 652-661.

39. Melovic, B., Ishkov, A., \& Romanovich, M. (2016). Branding companies as a factor of competitiveness - relevance for the engineering management. Procedia Engineering, 165, 1563-1567.

40. Mineraud, J., Mazhelis, O., Su, X., \& Tarkoma, S. (2016). A gap analysis of Internet-of-Things platforms. Computer Communications, 89/90, 5-16.

41. Murin, I., Marková, I., Zeleny, J., \& Jad'ud'ová, J. (2015). GM as a tool influencing consumers' behavior: Slovak case study of regional mark preference. Procedia Economics and Finance, 34, 260-267.

42. Olbrich, R., Jansen, H. C., \& Hundt, M. (2017). Effects of pricing strategies and product quality on private label and national brand performance. Journal of Retailing and Consumer Services, 34, 294-301.

43. Po, B., \& Woratschek, H. (2017). Consumers' relationships with brand communities - The multifaceted roles of identification and satisfaction. Journal of Retailing and Consumer Services, 35, 46-56.

44. Porter, M. E. (1981). The contributions of industrial organization to strategic management. Academy of management review, 6(4), 609-620.

45. Preece, C., Moodley, K., Smith, P., \& Collar, P. (2003). Construction business development: meeting new challenges, seeking opportunity. Oxford: Elsevier. 
46. Prosenak, D., Mulej, M., \& Snoj, B. (2008). A requisitely holistic approach to marketing in terms of social well-being. Kybernetes, 37(9/10), 508-1529.

47. Qi, A., \& Chen, H. (2014). Research on China construction project management paradigms change and development in the last 30 years. Procedia Social and Behavioral Sciences, 119, 321 328.

48. Quoquab, F., \& Mohammad, J. (2016). Environment dominant logic: concerning for achieving the sustainability marketing. Procedia Economics and Finance, 37, 234-238.

49. Ramsey, J. (2001). The resource-based perspective, rents, and purchasing's contribution to sustainable competitive advantage. Journal of Supply Chain Management, 37(3), 38-47.

50. Rust, R. T., Kumar, V., \& Venkatesan, R. (2011). Will the frog change into a prince? Predicting future customer profitability. International Journal of Research in Marketing, 28, 281-294.

51. Sacui, V., \& Dumitru, F. (2014). Market-based assets. Building value through marketing investments. Procedia Social and Behavioral Sciences, 124, 157-164.

52. Salamandic, E., Alijosiene, S., \& Gudonaviciene, R. (2014). Price sensitivity measurement depending on brand awareness: A case of Ziede brand. Procedia Social and Behavioral Sciences, 156, 473478.

53. Salvia, A. L., Filho, W. L., Brandli, L. L., \& Griebeler, J. S. G. (2019). Assessing research trends related to sustainable development goals: local and global issues. Journal of Cleaner Production, 208, 841-849.

54. Sanclemente-Tellez, J. C. (2017). Marketing and corporate social responsibility (CSR). Moving between broadening the concept of marketing and social factors as a marketing strategy. Spanish Journal of Marketing - ESIC, 21, 4-25.

55. Santoz-Vijande, M. L., Rio-Lanza, A. B., Suarez-Alvarez, L., \& Diaz-Martin, A. M. (2013). The brand management system and service firm competitiveness. Journal of Business Research, 66, 148-157.

56. Scheinbaum, A. C., \& Lacey, R. (2015). Event Social Responsibility: A Note to Improve Outcomes for Sponsors and Events. Journal of Business Research, 68, 1982-1986.

57. Setiawan, H., Erdogan, B., \& Ogunlana, S. O. (2015). Proactiveness of Contractors: A Study of Indonesia. Procedia Engineering, 125, 60-67.

58. Shang, J., Basil, D. Z., \& Wymer, W. (2010). Using Social Marketing to Enhance Hotel Reuse Programs. Journal of Business Research, 63, 166-172.

59. Shi, L., Ye, K., Lu, W., \& Hu, X. (2014). Improving the Competence of Construction Management Consultants to Underpin Sustainable Construction in China. Habitat International, 41, 236-242.

60. Simão, L., \& Lisboa, A. (2017). Green Marketing and Green Brand - The Toyota Case. Procedia Manufacturing, 12, 183-194.

61. So, K. K. F., King, C., Hudson, S., \& Meng, F. (2017). The missing link in building customer brand identification: The role of brand attractiveness. Tourism Management, 59, 640-651.

62. Tirole, J. (1988). The Theory of Industrial Organization. Boston, MA: The MIT Press.

63. United Nations Department of Economic and Social Affairs (2008). International Standard Industrial Classification of All Economic Activities (ST/ESA/STAT/SER.M/4/Rev.4). New York, NY: UN.

64. Verrier, B., Rose, B., \& Caillaud, E. (2016). Lean and Green Strategy: The Lean and Green House and Maturity Deployment Model. Journal of Cleaner Production, 116, 150-156.

65. Vveinhardt, J., \& Zyngmantaite, R. (2015). Impact of Social Context on Strategic Philanthropy: Theoretical Insight. Procedia Social and Behavioral Sciences, 214, 1165-1173.

66. Wang, Y., \& Tzeng, G. (2012). Brand Marketing for Creating Brand Value Based on a MCDM Model Combining DEMATEL with ANP and VIKOR Methods. Expert Systems with Alications, 39, 5600-5615.

67. Winch, G. M. (2006). Towards a Theory of Construction as Production by Projects. Building Research and Information, 34(2), 164-174. 
68. World Trade Organization (WTO) (2017). Services: Service Sectors Sector-By-Sector Information. Retrieved from https://www.wto.org/english/tratop_e/serv_e/serv_sectors_e.htm (accessed 20 April 2020).

69. Wu, P., Low, S. P., \& Jin, X. (2013). Identification of non-value adding (NVA) activities in precast concrete installation sites to achieve low-carbon installation. Resources, Conservation and Recycling, 81, 60-70.

70. Yadav, R., \& Pathak, G. S. (2013). GM: Initiatives in the Indian Context. Indian Journal of Marketing, 43(10), 25-32.

71. Zhang, J., Jiang, Y., Shabbir, R., \& Du, M. (2015). Building Industrial Brand Equity by Leveraging Firm Capabilities and Co-Creating Value with Customers. Industrial Marketing Management, 51, 47-58.

72. Zhou, L., Li, J., \& Chiang, Y. H. (2013). Promoting energy efficient building in China through clean development mechanism. Energy Policy, 57, 338-346.

73. Zhu, Q., \& Sarkis, J. (2016). GM and consumerism as social change in china: analyzing the literature. International Journal of Production Economics, 181, 289-302. 